\title{
THE EVOLUTION OF LAWYERS' PROFESSIONAL IDENTITY: THE CONTRIBUTION OF ADR IN LEGAL EDUCATION
}

\section{KATHY DOUGLAS*}

\begin{abstract}
Alternative or Appropriate Dispute Resolution ('ADR') is a crucial area for lawyers to understand in order to engage in present day legal practice. $A D R$ is now common in courts and the community and is supported by legal policy at both federal and state levels. Learning about ADR can contribute to the moulding of law students' professional identity so that they are better able to engage in commonly used processes such as negotiation and mediation. This article discusses research into the teaching of $A D R$ in legal education. It draws on a project where the teaching of $A D R$ was researched in depth to examine the content and pedagogy of this area of the legal curriculum. The article argues that $A D R$ is an important part of legal education as it can assist law students to develop non-adversarial, holistic approaches to legal problem-solving.
\end{abstract}

\section{INTRODUCTION}

According to one influential academic, Julie Macfarlane, lawyers' practice in Canada and the United States is turning from a focus on rights-based paradigms to approaches that incorporate the full range of options to address conflict, including negotiation and mediation. ${ }^{1}$ In Australia too there have been changes to lawyers' practice due to increased use of alternative or appropriate dispute resolution ('ADR') in courts and the community in an effort to reduce the cost of justice and provide a speedy and informal alternative to litigation. ${ }^{2}$ Governments in Australia, both federal and state, increasingly promote the use of ADR through policy and legislative

\footnotetext{
* BA, LLM (Monash University), Dip Ed (Melbourne University), PhD (RMIT University), Senior Lecturer, Graduate School of Business and Law, RMIT University.

${ }^{1}$ Julie Macfarlane, The New Lawyer: How Settlement is Transforming the Practice of Law (University of British Columbia Press, 2008) ch 1.

${ }^{2}$ Tania Sourdin, 'Not Teaching ADR in Law Schools? Implications for Law Students, Clients and the ADR Field' (2012) 23 Australasian Dispute Resolution Journal 148, 150.
} 
initiatives. ${ }^{3}$ The teaching of ADR as part of legal education is thus an important issue when the present day legal curriculum is considered. Recently, the National Alternative Dispute Resolution Council ('NADRAC') conducted a study into the teaching of ADR in Australian law schools. ${ }^{4}$ This research found that ADR is taught in many law schools in Australia, although in some law schools it remains an elective. ${ }^{5}$ NADRAC argues that legal education makes an important contribution to changing the culture of the legal profession to include non-adversarial means of dispute resolution and to help lawyers understand that ADR may have many benefits 'including preserving relationships and achieving an outcome that all parties can accept'. ${ }^{6}$ The Council advocated that ADR be more widely included in legal education in Australia. $^{7}$

NADRAC used primarily survey data to establish the place of ADR in the legal curriculum. ${ }^{8}$ Although invaluable in establishing the current state of play in ADR teaching in Australia, and lobbying for greater inclusion of ADR in law programs, the NADRAC study does not provide sufficient analysis of the content and pedagogy of ADR and how it may contribute to the development of lawyers' professional identity. This article provides insights into the teaching lives of ADR law lecturers. It outlines selected findings from the author's doctoral study, exploring the stories of teachers of ADR in selected Australian law schools and their perceptions of the ways ADR contributes to the evolving professional identity of lawyers. The aim of this research was to explore the content and pedagogies used by law teachers in teaching the discipline area of ADR. The research was primarily constructivist and considered the teaching of ADR in two states in Australia: Victoria and Queensland.

\footnotetext{
3 Brendan French, 'Dispute Resolution in Australia: The Movement from Litigation to Mediation’ (2007) 18 Australasian Dispute Resolution Journal 213, 214; Tania Sourdin, 'Civil Dispute Resolution Obligations: What is Reasonable?' (2012) 35(3) University of New South Wales Law Journal 889, 889; Michael King et al, Non-Adversarial Justice (Federation Press, 2009), 99.

${ }^{4}$ NADRAC, Teaching Alternative Dispute Resolution in Australian Law Schools (November 2012) <http://www.nadrac. gov.au/publications/PublicationsA-Z/Pages/default.aspx\#TT>.

${ }^{5}$ Ibid 6-7.

${ }^{6}$ Ibid 4.

${ }^{7}$ Ibid 8.

${ }^{8}$ Ibid 3. The survey was sent to 32 law schools in all states of Australia and was conducted in late 2010 to early 2011. Twenty-seven law schools responded to the survey. The NADRAC report additionally draws upon discussion at the forum $A D R$ in Legal Education and Promoting Student Wellbeing Forum, held at RMIT University, 20-21 February 2012. Also the report included NADRAC's own research and the expertise of its members.
} 
This article begins by discussing the contribution that ADR can make to lawyers' professional identity. It describes the literature relating to the evolving identity of lawyers as non-adversarial practitioners. It then discusses current ADR content and pedagogy and the ways that ADR can contribute to a non-adversarial orientation to legal practice. The article then describes the methodology of, and selected findings from, the author's doctoral dissertation on ADR in Australian law schools. It concludes that ADR has an important role to play in shaping lawyers of the future to deal with changing paradigms in legal practice.

\section{LAWYERS AND ADR}

The adoption of non-adversarial approaches is growing in Australian legal practice. ${ }^{9}$ Lawyers have always engaged in negotiation and problem-solving for their clients, as only a small percentage of matters reach a full court hearing. ${ }^{10}$ Furthermore, as a result of changes to the Australian legal and justice system sections of the legal profession have increasingly adopted nonadversarial approaches in response to the context - for example the family context — of the legal problem. ${ }^{11}$ Importantly, 'ADR mechanisms have now been incorporated into the formal justice system throughout Australia' ${ }^{12}$ Amendments to family law legislation, for example, have included the requirement that the parties engage in genuine negotiation in family dispute resolution to assist this culture change. ${ }^{13}$ The inclusion of requirements that negotiations be 'genuine' or conducted in 'good faith' is becoming more common in legislation relating to dispute resolution. ${ }^{14}$ In 2009 NADRAC recommended that legislation be passed in the federal jurisdiction that

\footnotetext{
${ }^{9}$ King et al, above n 3, 230-1.

${ }^{10}$ Ibid 6-16.

${ }^{11}$ Family Law lawyers have a history of engagement with ADR and increasingly show a sophisticated understanding of their possible roles in alternative processes: Donna Cooper and Mieke Brandon, 'Lawyers' Role Options in Family Dispute Resolution' (2011) 22 Australasian Dispute Resolution Journal 198.

12 Stephen Colbran, Peta Spender, Sheryl Jackson and Roger Douglas, Civil Procedure: Commentary and Materials (LexisNexis, $5^{\text {th }}$ ed, 2012) 75.

${ }^{13}$ See Family Law Act 1975 (Cth) s 601.

${ }^{14}$ NADRAC, Legislating for Alternative Dispute Resolution: A Guide for Government PolicyMakers and Legal Drafters (November 2006) 44-6 <http://www.nadrac.gov.au/publications/ PublicationsByDate/Documents/Legislating\%20for\%20Alternative\%20Dispute\%20Resolutio n.pdf>; Bobette Wolski, 'An Evaluation of the Rules of Conduct Governing Legal Representatives in Mediation: Challenges for Rule Drafters and a Response to Jim Mason' (2013) 16(1) Legal Ethics 182, 199.
} 
included a requirement for 'genuine steps' to be taken prior to litigation ${ }^{15}$ and this recommendation resulted in the passing of the Civil Dispute Resolution Act 2011 (Cth). This legislation requires engagement with the dispute prior to formal action being taken. Under sections 6-7, applicants and respondents must file 'genuine steps' statements prior to litigating. These genuine steps statements must include detail about the parties' initiatives to engage with the dispute in a manner that promotes settlement. The options available to the parties are wider than ADR and may merely involve the sharing of information such as the details of a claim, prior to litigating. Under section 9 lawyers have a duty to advise clients of the need to file a genuine steps statement and must assist them to do so.

Changes to civil procedure in Victoria were introduced through the Civil Procedure Act 2010 (Vic). Section 1(2) of the Act provides for an enhancement of judicial case management powers, with the prioritisation of ADR and the early facilitation of dispute settlement. The legislation thus attempts to promote access to justice through the improved use of case management and ADR. However, after a change of government, ${ }^{16}$ one of the key features of the new civil procedure legislation - the pre-litigation requirements - was repealed. Under chapter 3 of the Act lawyers were required to engage in negotiation and information sharing prior to litigation. This initiative was repealed by the Civil Procedure and Legal Profession Amendment Act 2011 (Vic), in response to criticism by Victorian lawyers that the pre-litigation requirements were too burdensome on the legal profession and potentially added to the costs of proceedings. ${ }^{17}$

Other provisions of the legislation dealing with ADR have been retained. The legislation imposes various obligations under chapter 2, relating to the 'overarching purpose' and 'overarching obligations' that affect the ways that judges, lawyers and clients behave in the civil justice system, and require all participants to be responsible for the just, efficient, timely and cost-effective resolution of issues in dispute. As part of the widened use of ADR and case

\footnotetext{
${ }^{15}$ NADRAC, The Resolve to Resolve: Embracing ADR to Improve Access to Justice in The Federal Jurisdiction 7, 30 (September 2009). <http://www.nadrac.gov.au/publications/ PublicationsByDate/Documents/TheResolvetoResolve.pdf>.

${ }^{16}$ In November 2010 the Labor government was defeated by the Liberal/National Coalition opposition.

${ }^{17}$ Explanatory Memorandum, Civil Procedure and Legal Profession Amendment Bill 2011 (Vic) 1. See also Michael Brett Young, 'New Broom Sweeps Cleanly' (2011) 85(5) Law Institute Journal 6. The repealed ch 3 of the Civil Procedure Act 2010 (Vic) 'required disputants to use alternative dispute resolution (ADR) processes, [that] were burdensome and unworkable and had the potential to undermine the overall intention of the civil procedure reforms': at 6. For an overview of the Civil Procedure Act 2010 see Mary-Anne MacCallum and Richard Vinciullo, 'Smoother Sailing with ADR' (2011) 85(3) Law Institute Journal 36.
} 
management provisions under the legislation, lawyers and parties are obliged to engage in all opportunities for settlement of a dispute. For example, under section 22 lawyers and parties 'must use reasonable endeavours' to resolve disputes, which may include the use of ADR. Under section 23 ADR can also be used to, at least, 'narrow the scope of the ... issues in dispute', even if resolution is not possible through ADR. Under sections 66-68 the Act explicitly promotes 'appropriate dispute resolution' and includes the option of mandatory mediation and other non-binding ADR processes. ${ }^{18}$

Legal practice is also changing in the United States and Canada, where new paradigms of legal practice that promote more holistic approaches are gaining momentum. ${ }^{19}$ In a sustained critique of the adversarial system and legal culture Menkel-Meadow $^{20}$ argues that the adversarial system should be confined only to those disputes for which it is appropriate, and that the legal profession and parties should consider other options including multi-person, multi-perspective, deliberative and participative processes to more adequately satisfy the full range of human needs in conflict. ${ }^{21}$ She also contends that the spectrum of ADR processes helpfully contributes to the plurality of options in our legal system, and cautions that lawyers must resist 'importing' adversarial values into these new approaches. ${ }^{22}$ Thus, she argues that '[1]awyers and third-party neutrals will clearly have to learn new roles to play in mediation'. ${ }^{23}$ Greater choice in dispute resolution options gives lawyers the opportunity to practise in a variety of ways and within differing ethical frameworks. ${ }^{24}$ It is therefore important for lawyers to be educated in the full range of dispute resolution options available.

However, Leonard Riskin has identified the paradigm in legal education of the 'lawyers' philosophical map' whereby law students learn to see legal problems as disputes that should be decided by a third party. ${ }^{25}$ This approach to law students' education privileges a rights-based, litigious framework of dispute resolution. The lawyers' philosophical map is learnt through a focus

\footnotetext{
${ }^{18}$ The legislation also includes certification requirements which have been amended by the Civil Procedure Amendment Act 2012 (Vic) ss 12-17.

${ }^{19}$ See generally Carrie Menkel-Meadow, 'Ethics in Alternative Dispute Resolution: New Issues, No Answers from the Adversary Conception of Lawyers' Responsibilities' (1997) 38(2) South Texas Law Review 407; Macfarlane, above n 1, $22-4$.

${ }^{20}$ Carrie Menkel-Meadow, 'The Trouble with the Adversary System in a Postmodern Multicultural World’ (1996) 38(3) William and Mary Law Review 5.

${ }^{21}$ Ibid 42.

${ }^{22}$ Ibid 37.

${ }^{23} \mathrm{Ibid}$.

${ }^{24}$ Ibid 43.

${ }^{25}$ Leonard Riskin, 'Mediation and Lawyers' (1982) 43(1) Ohio State Law Journal 29, 43-4.
} 
on appellate decisions in legal pedagogy and leads lawyers to see their role as persuasively arguing for the legal rights of their clients in a manner that convinces a court of the superiority of their claims. Then, rather than seeking to persuade the other party of the justice of their arguments, lawyers seek to convince a court of the soundness of their legal reasoning. ${ }^{26}$ In this frame of practice a lawyer will strive to gain the upper hand against the opponent. This approach may lead to excessively zealous conduct in adversarial advocacy for the client. ${ }^{27} \mathrm{~A}$ focus upon legal rights may obscure the underlying issues in dispute 'since rights arguments are couched in terms of right and wrong rather than in terms of what is expedient, feasible, or wise' ${ }^{28}$ The default to a rightsbased approach can also mean that there is a belief in the possibility of a 'win' right up to the courtroom door. But since much litigation is ultimately settled prior to trial, this approach can result in last minute compromises that fail to deal with all the concerns of clients and mean that clients are charged for the preparation of a case that does not proceed. Use of a rights-based framework in legal practice may neglect the practical and emotional issues in disputes, and potentially rob a client of the opportunity to deal with these issues. ${ }^{29}$

An adversarial approach to mediation also jeopardises the possible benefits of the process — such as the parties' sense of self-determination — by introducing rights-based and combative tactics to the mediation room. The institutionalisation of mediation has resulted, in some court-connected programs, in the rise of an evaluative, as opposed to a facilitative, model of mediation. ${ }^{30}$ In the facilitative model party empowerment is emphasised, the parties making their own decisions by engaging in collaborative problemsolving. ${ }^{31}$ In the evaluative model, parties are given advice by the mediator about such matters as the likely court outcomes should the parties proceed to trial. One significant criticism of the evaluative model is that sometimes in

\footnotetext{
${ }^{26}$ Ibid, 43-5.

${ }^{27}$ Macfarlane, above n 1, 49.

${ }^{28}$ Ibid 50.

${ }^{29}$ Michael S King, 'Restorative Justice, Therapeutic Jurisprudence and the Rise of Emotionally Intelligent Justice’ (2008) 32(3) Melbourne University Law Review 1096; Macfarlane, above n 1, 53.

${ }^{30}$ Nancy Welsh, 'The Thinning Vision of Self-Determination in Court-Connected Mediation: The Inevitable Price of Institutionalization?' (2001) 6(1) Harvard Negotiation Law Review 1, 27-8. In Victoria research has pointed to the use of evaluative mediation in some contexts in the Supreme and County Courts and the negative impact upon the parties' experience of the process (although overall satisfaction with mediation was evident in the research): Tania Sourdin and Nikola Balvin, 'Mediation in the Supreme and County Courts of Victoria: A Summary of the Results’ (2009) 11(3) Alternative Dispute Resolution Bulletin 41, 45.

${ }^{31}$ Carole Brown, 'Facilitative Mediation: The Classic Approach Retains Its Appeal' (20032004) 4(2) Pepperdine Dispute Resolution Law Journal 279, 281-2.
} 
evaluative mediation the mediator exerts pressure on the parties to settle, thus diminishing party self-determination and decision-making. ${ }^{32}$

Similarly, the behaviour of lawyers as representatives in mediation may undermine the aims of facilitative and other forms of mediation. For example, Parker and Evans have observed that some lawyers engaged in mediations in Australia may adopt an adversarial approach. ${ }^{33}$ One reason for this behaviour may be that it is the unconscious extension of habits more suited to the courtroom. However, Parker and Evans note that excessive adversarialism, manifested as aggression, emotional posturing, misleading conduct, and bullying may also be adopted by lawyers as a tactic to subvert the purposes of mediation and ADR. ${ }^{34}$ Macfarlane argues that the construct of adversarialism has a high status that privileges and reifies the adversarial orientation. ${ }^{35}$ This high status, combined with the generally privileged position of many lawyers, ${ }^{36}$ may mean that lawyers are reluctant to change the status quo. ${ }^{37}$ Importantly, the use of a rights based paradigm in legal practice may neglect the practical and emotional issues in disputes, and potentially deny a client the opportunity to deal with these concerns. ${ }^{38}$ One of the ways to contribute to the development of lawyers of the future, who are able to draw on a nonadversarial framework in practice, is through the teaching of ADR in legal education. The history of ADR in legal education shows that it is a prime site for the development of a non-adversarial practice, and non-adversarially minded practitioners.

\footnotetext{
32 Lela P Love, 'The Top Ten Reasons Why Mediators Should Not Evaluate' (1996-1997) 24(4) Florida State University Law Review 937. Some commentators argue that the rise of evaluative mediation is inevitable: see, eg, Jeffrey W Stemple, 'The Inevitability of the Eclectic: Liberating ADR from Ideology’ [2000] 2 Journal of Dispute Resolution 247. For a contrary view, see Lela Love and Kimberlee Kovach, 'ADR: An Eclectic Array of Processes, Rather than One Eclectic Process' [2000] 2 Journal of Dispute Resolution 295.

${ }^{33}$ Christine Parker and Adrian Evans, Inside Lawyers' Ethics (Cambridge University Press, 2007) 122.

${ }^{34}$ Ibid.

${ }^{35}$ Macfarlane, above n 1, 101.

${ }^{36}$ With the increase in law programs in Australia there has been a widening of the socioeconomic and ethnic backgrounds of law students: Susanne Owen and Gary Davis, Learning and Teaching in the Discipline of Law: Achieving and Sustaining Excellence in a Changed and Changing Environment (Australian Learning and Teaching Council, 2009) 43-7.

${ }^{37}$ Macfarlane, above n 1, 27.

${ }^{38}$ Michael S King, above n 29, 1096; Macfarlane, above n 1, 53.
} 


\section{ADR Content And Pedagogy}

Before the 1980s ADR was not widely included in law school education. Initial debates about legal education and ADR centred on the need to include this discipline area in the law curriculum. ${ }^{39}$ NADRAC's recent research along with research in the United States ${ }^{40}$ shows that in the last thirty years, ADR has become accepted in most law schools in the two countries, albeit often as an elective. Some universities in Australia include ADR as a compulsory first year subject, often termed Dispute Resolution, to indicate that the area should not be seen as an alternative to litigation but as one of a spectrum of legal choices. ${ }^{41}$ Less frequently it may be a compulsory later year subject in the program. ${ }^{42}$ Other law programs combine ADR with civil procedure. ${ }^{43}$ In this approach the discussion of ADR is integrated with the teaching of a traditional core subject.

The teaching of ADR, unlike that of many substantive and procedural legal subjects, does not generally rely heavily on cases and legislation, although there have been increasingly more doctrinal developments in this area. ${ }^{44}$ Pipkin argues that approaches to ADR teaching in law school had their genesis in negotiation and mediation short-course training that was originally offered by institutions such as Harvard University. ${ }^{45}$ The Harvard negotiation integrative bargaining model was made famous by Roger Fisher and William Ury. ${ }^{46}$ This model, which includes creative problem-solving and 'win win'

39 Australian Law Reform Commission, Review of the Adversarial System of Litigation: Rethinking Legal Education and Training, Issues Paper No 25 (1998) [5.7].

${ }^{40}$ Michael Moffitt, 'Islands, Vitamins, Salt, Germs: Four Visions of the Future of ADR in Law Schools (and a Data-Driven Snapshot of the Field Today)' (2010) 25(1) Ohio St Journal on Dispute Resolution 25.

${ }^{41}$ See, eg, Tom Fisher, Judy Gutman and Erika Martens, 'Why Teach Alternative Dispute Resolution to Law Students Part 2: An Empirical Survey’ (2007) 17 Legal Education Review 67; Hilary Astor and C M Chinkin, 'Dispute Resolution as Part of Legal Education' (1990) 1 Australian Dispute Resolution Journal 208.

${ }^{42}$ See, eg, Pauline Collins, 'Students' Reflections on the Benefits of Studying ADR to Provide Experience of Non-Adversarial Practice’ (2012) 23 Australasian Dispute Resolution Journal 204.

${ }^{43}$ See, eg, Kathy Mack, 'Integrating Procedure, ADR and Skills: New Teaching and Learning for New Dispute Resolution Processes’ (1998) 9(1) Legal Education Review 83. More generally ADR may be integrated into a variety of core courses: Jeff Giddings, 'Why No Clinic Is an Island: The Merits and Challenges of Integrating Clinical Insights across the Law Curriculum' (2010) 34 Washington University Journal of Law and Policy 261, 267, 277.

${ }^{44}$ NADRAC, Teaching, above n 4, 13-14.

${ }^{45}$ Ronald Pipkin, 'Teaching Dispute Resolution in the First Year of Law School: An Evaluation of the Program at the University of Missouri-Columbia' (1998) 50(4) Florida Law Review 610, 651-2.

${ }^{46}$ Roger Fisher, William Ury and Bruce Patton, Getting to Yes: Negotiating Agreement without Giving In (Penguin Group, 1991). 
solutions, is the most widely accepted approach to negotiation in the ADR field. ${ }^{47}$ The Harvard approach positions itself in opposition to adversarial, distributive approaches to negotiation which are centred on winning and an opponent losing. Early in the evolution of ADR teaching in the legal curriculum, academics offered these negotiation and mediation courses as electives in law schools, and adopted the Harvard frame of practice and the widely used role-play pedagogy. ${ }^{48}$ One of the benefits of the role-play pedagogy in ADR courses is that this approach is more active than in most traditional law courses. Such role-play pedagogy employs experiential learning techniques/concepts that incorporate authentic learning scenarios. ${ }^{49}$ Courses often include learning about the knowledge and skills used by a mediator in disputes through experiential role-plays. ${ }^{50}$ This course area may also include consideration of the role of the lawyer ${ }^{51}$ in the ADR processes. Australian research at La Trobe University has shown that, through studying negotiation and mediation, law students can shift from an adversarial approach to legal problems to a more collaborative problem-solving approach. $^{52}$

The dominance of the Harvard approach has caused increasing critique of the mode of teaching negotiation and mediation. ${ }^{53}$ Western constructs of conflict dominate in this Harvard approach, potentially marginalising those from cultures different from that of the United States. ${ }^{54}$ The model may also place too much reliance on role-plays, and more variety of pedagogical methods

\footnotetext{
${ }^{47}$ Michelle LeBaron and Mario Patera, 'Reflective Practice in the New Millennium' in Christopher Honeyman, James Coben and Giuseppe De Palo (eds), Rethinking Negotiation Teaching: Innovations for Context and Culture (DRI Press, 2009) 48.

${ }^{48}$ Pipkin above n 45, 646.

${ }^{49}$ Michael Moffitt, 'Lights, Camera, Begin Final Exam: Testing What We Teach in Negotiation Courses' (2004) 54 Journal of Legal Education 91. Note that active learning generally results in 'deep' learning for students; students engage more deeply with content: Paul Ramsden, Learning to Teach in Higher Education (Routledge, $2^{\text {nd }}$ ed, 2003) 151-2.

${ }^{50}$ Edwin Greenebaum, ‘On Teaching Mediation’ [1999] 2 Journal of Dispute Resolution 115.

${ }^{51}$ Suzanne J Schmitz, 'Giving Meaning to the Second Generation of ADR Education: Attorneys' Duty to Learn about ADR and What They Must Learn' [1999] 1 Journal of Dispute Resolution 30.

${ }^{52}$ Fisher et al, above $\mathrm{n} 41$.

${ }^{53}$ Kenneth Fox, 'Negotiation as a Post-Modern Process' in Christopher Honeyman, James Coben and Giuseppe De Palo (eds), Rethinking Negotiation Teaching: Innovations for Context and Culture (DRI Press, 2009) 13.

${ }^{54}$ Phyllis Bernard, 'Finding Common Ground in the Soil of Culture' in Christopher Honeyman, James Coben and Giuseppe De Palo (eds), Rethinking Negotiation Teaching: Innovations for Context and Culture (DRI Press, 2009) 29.
} 
may be necessary. ${ }^{55}$ Importantly, the integrative bargaining approach and facilitative mediation may not be what students experience when leaving university, as more adversarial, distributive approaches are often used in practice, and, at times, these may be the more appropriate models of dispute resolution. ${ }^{56}$ More broadly, legal education in Australia increasingly acknowledges the need to teach legal skills as well as substantive knowledge of areas of the law. ${ }^{57}$ Legal education needs to prepare lawyers for practice, and knowledge and skills in ADR are thus central. ADR is both an area of substantive knowledge, and a legal skill. ${ }^{58}$ As such it sits between traditional doctrinal courses and courses framed solely around legal skills. ${ }^{59}$

With the release of 'threshold learning outcomes' ('TLOs') in law as part of a federal government initiative in tertiary standards, there is better understanding in academia of the need for legal education to meet a variety of curriculum aims. ${ }^{60}$ These TLO standards came about through the 2008 report into tertiary education, Review of Australian Higher Education. ${ }^{61}$ The report noted that the reach and standard of higher education in Australia had begun to lag behind other Organisation for Economic Co-operation and Development ('OECD') countries and that Australia needed to increase funding, improve staff/student ratios and value teaching in universities and other providers. ${ }^{62}$ Amongst a number of recommendations, the report called for a national quality assurance regime in higher education. In response to this report, the Australian federal government introduced a regulatory regime to ensure quality in the tertiary sector. This regime requires all higher education providers to meet threshold standards in order to enter and remain in the sector. $^{63}$ The Tertiary Education Quality and Standards Agency was

\footnotetext{
${ }^{55}$ Nadja Alexander and Michelle LeBaron, 'Death of the Role-Play' in Christopher Honeyman, James Coben and Giuseppe De Palo (eds), Rethinking Negotiation Teaching: Innovations for Context and Culture (DRI Press, 2009) 179.

${ }^{56}$ Paul Kirgis, 'Hard Bargaining in the Classroom: Realistic Simulated Negotiations and Student Values' (2012) 28(1) Negotiation Journal 93, 96-8. See also Larry Crump and Jeff Giddings, 'Strategy Choice and the Skilled Legal Negotiator' (2005) 31(2) Monash University Law Review 258, 259-60.

${ }^{57}$ Richard Johnstone, 'Whole of Curriculum Design in Law' in Sally Kift et al (eds), Excellence and Innovation in Legal Education (LexisNexis Butterworths, 2011) 2.

${ }^{58}$ Riskin above n 25, 63.

${ }^{59}$ Bobette Wolski, 'Reform of the Civil Justice System Two Decades Past - Implications for the Legal Profession and for Law Teachers' (2009) 21(3) Bond Law Review 192, 221-5.

${ }^{60}$ Margaret Castles and Anne Hewitt, 'Can a Law School Help Develop Skilled Legal Professionals’ (2011) 36(2) Alternative Law Journal 90, 90-1.

${ }^{61}$ Denise Bradley et al, Australian Government, Review of Australian Higher Education (2008) (the 'Bradley Report').

${ }^{62}$ Ibid xi-xvi.

63 Tertiary Education Quality and Standards Agency ('TEQSA'), About TEQSA (2012) $<$ http://www.teqsa.gov.au/about>.
} 
established through the passing of the Tertiary Education Quality and Standards Agency Act 2011 (Cth) to oversee the sector. The agency regulates and evaluates tertiary providers. In 2010, funding was provided to develop benchmark standards in law, as part of a new Higher Education Quality and Regulatory Framework, these standards being completed in December 2010 . $^{64}$

The TLOs offer the greatest opportunities for affirming the place and strengthening the teaching of ADR in the law school curriculum. There are six TLOs: TLO 1: Knowledge, TLO 2: Ethics and professional responsibility, TLO 3: Thinking skills, TLO 4: Research skills, TLO 5: Communication and collaboration and TLO 6: Self-management. ${ }^{65}$ ADR is relevant to a number of TLOs including TLOs 1, 3, 5, and 6. In particular, ADR can provide learning in communication and collaboration as negotiation and mediation require communication and collaborative skills which are often attained through experiential role-play. NADRAC in its recent report on ADR in legal education stated:

The main reason law schools introduced ADR subjects was to meet the requirements of teaching and learning outcomes, which increasingly focus on the practical skills and a broader professional knowledge required by lawyers to service their clients. ${ }^{66}$

NADRAC's research received survey responses from 27 of the then available 32 law schools. According to the data eight law schools include a compulsory unit in which at least 50 per cent of the of the teaching is devoted to ADR and 25 of the law schools offered elective subjects in the area. ${ }^{67}$ The study revealed an overall trend to increased teaching of ADR, but there appeared to be few schools that included a mandatory stand-alone course in ADR, and most offered electives. Often ADR was taught as part of a civil procedure course. ${ }^{68}$ The research demonstrates the increasing acceptance of ADR in the legal curriculum and its growth as a core course. However, as a survey, the NADRAC research did not provide detailed insights into the content and pedagogy of ADR. The study discussed in this article redresses the balance by providing the kind of 'thick' descriptions of ADR content and pedagogy that will assist with understanding current practice and imagining new ways to

\footnotetext{
${ }^{64}$ Sally Kift, Mark Israel and Rachael Field, Learning and Teaching Academic Standards Project: Bachelor of Laws: Academic Standards Statement (December, 2010) Australian Teaching and Learning Standards <http://www.olt.gov.au/resource-law-ltas-statement-altc2010>. Notably, these standards are for undergraduate law programs but Juris Doctor (postgraduate law programs) standards have also been developed.

${ }^{65}$ Ibid 10.

${ }^{66}$ NADRAC, above n $4,7$.

${ }^{67}$ Ibid 9.

${ }^{68}$ Ibid.
} 
teach this area so that it better contributes to lawyers' professional identity as non-adversarial practitioners.

\section{Methodology}

The research that is the subject of this article addresses the teaching of ADR by Australian university law lecturers and considers the content and pedagogy of ADR subjects. It is a detailed study of the area of ADR, in contrast to the recent NADRAC study that used primarily survey data.

The study ${ }^{69}$ considers the experience of teaching ADR in law schools in Australia, and considers the content and pedagogy of ADR courses from the perspective of teachers. The data was gathered in the main during 2008. Qualitative data about the experience of teaching ADR was obtained through interviews with 24 teachers in Victoria and Queensland who taught ADR or a combination ADR course - that is, where ADR was combined with another discipline area such as civil procedure. One teacher from a New South Wales law school was interviewed on the recommendation of other participants due to her knowledge of ADR and legal education. Primarily quantitative data was gathered from a further five ADR teachers in Queensland through a survey, as time and budget constraints did not permit these teachers being interviewed. This survey used a Likert scale and mirrored the questions posed in the interviews. $^{70}$ The study also included a content analysis of 13 ADR law course guides for the main ADR subjects, obtained from teachers in the study, as well as analysing course guide information accessed from the world-wideweb pages of the relevant universities. Three additional law ADR course guides and two social science ADR guides were also examined.

\section{The Need to Teach ADR}

Analysis of the interview and survey data and the content analysis of the course guides show that all the participants in this study recognised the value of teaching ADR. The majority emphasised student understanding of nonadversarial options in practice. Teachers believed that a comprehensive

\footnotetext{
${ }^{69}$ Kathy Douglas, The Teaching of Alternative Dispute Resolution in Selected Australian Law Schools: Towards Second Generation Practice and Pedagogy, unpublished thesis, RMIT University, 2012.

${ }^{70}$ Each of the interviewed or surveyed teachers was asked for background information relating to that person's socio-demographic characteristics. There were also some open-ended questions at the end of the survey. The data gathered from the interviews and surveys was separated from the participants and coded to elicit themes.
} 
understanding of ADR processes was necessary for a lawyer to fully advise a client:

[I]t's about the students gaining an awareness of the limitations of litigation models, the potential for making use of other processes and the need to fit the approach to the context.

I believe it is important for lawyers to have the ADR string to their bow, if they are to properly advise their clients.

Additionally, many participants linked non-adversarial practice to the need to provide holistic problem-solving for clients. For example, one teacher reflected:

Well, it's linked to being focused on what is of most concern to a client but also to the others involved, so it's not just providing advice to your clients, it's encouraging your client to think about the other people who are going to be affected by a given situation. And ADR is really important in encouraging clients to think more carefully about just what it is that they need to be addressing.

These views were supported by the content analysis of the course guides. It was clear from the course guides in all of the 10 stand-alone ADR courses offered in law schools that non-adversarial practice was part of the curriculum. All of these course guides made some reference to lawyers' engagement with, and choice of, ADR processes and the possible ethical dilemmas of those choices. The aim of the stand-alone courses was to introduce ADR to students so that they could understand the opportunities these processes offered to those engaged in dispute resolution as well as to help students appreciate the limits of litigation. For example, the learning outcomes of one course in Queensland were as follows:

\section{LEARNING OUTCOMES}

By the end of this course, you should have:

1. Enhanced your understanding of the nature of conflict;

2. A greater appreciation of the range of processes used in efforts to manage conflict and resolve disputes;

3. Improved your awareness of the communication skills used in dispute resolution practice;

4. Developed your appreciation of the uncertainties of dispute resolution practice. You need to learn how to deal effectively with unstructured 
situations, how to work collaboratively as well as recognising the limitations of 'legal' solutions to some problems. You should also subject the legal system to analysis and criticism;

5. An enhanced understanding of the ethical and professional responsibilities owed by dispute resolution practitioners, including mediators and lawyers.

For the students taking this course this example demonstrates the overall commitment of the ADR law teacher to developing non-adversarial practice, understanding and skills.

\section{LAWYERS AND ADR}

The ADR teachers who participated in the interviews were asked their views about the approach of the legal profession to dispute resolution. Most participants believed that lawyers now dealt with ADR in practice, however they also expressed some scepticism about lawyers' level of commitment to the processes. One participant commented on lawyers' traditional frame of practice, where litigation is privileged, and contrasted that with a frame that prioritised the needs and perspectives of parties:

So from a lawyer's point of view, a dispute is resolved if it's litigated where the judge makes their decision. Now ... if you know anything, you know that it [litigation] doesn't necessarily resolve it either ... So what's the element of success? And is it an external thing or is it a ... ? Do you ask the parties? Do you ask both parties, one party?

Another participant also noted that litigation is privileged and that ADR is perceived as operating on the periphery of legal practice:

I think there's an acceptance that ADR is an acceptable part of the legal landscape, but it's not something that a lot of lawyers themselves feel is part of what they do.

Similarly, one participant regretted that learning about collaborative problemsolving approaches in ADR may not have any immediate impact on the privileging of adversarialism as the dominant paradigm of legal practice:

[E]ven though lawyers are embracing ADR ... if they come to the negotiation with an adversarial mindset, then what's the use of knowing anything about win/win or lose/lose? 
The privileging of litigation paradigms means that there may be an impact on the way that ADR is practised in the legal context. ${ }^{71}$ One participant in this study noted the 'colonisation' of mediation by lawyers, echoing concerns expressed by Menkel-Meadow that the institutionalisation of ADR will result in the colonisation of ADR by the adversarial system. ${ }^{72}$

[S]ome firms in Melbourne ... don't even take their clients into [the] mediation [room], they keep them right outside. Others take them in and the client doesn't get to say anything ... I mean, all professions will embrace new things if they have to, and then they will transform it into what they're used to and what they feel comfortable with ... But we always tell our students not to go out too idealistic because they're going to come up against a very strong culture ... basically a barrister/mediator just expressing an opinion or shuffling messages backwards and forwards [in the mediation]. However, in other areas and in some contexts there is a lot of scope for lawyer/mediators to do things differently and to empower clients and so on. But these things take a while to change. But I mean definitely some lawyers will be much more open to interest-based problem solving than would have been the case previously.

Although the majority of teachers of stand-alone ADR courses shared this view of the legal profession, those who taught ADR combined with civil procedure appeared more confident about the place of ADR in litigation. This confidence may not be unequivocal as two out of three teachers of combined courses saw ADR simply as a case management tool rather than a process that incorporated integrative bargaining.

One of the key areas of research of this investigation concerned the various models of negotiation and mediation taught in ADR courses in legal education. Analysis of the data shows that when teachers taught ADR in a stand-alone course, the dominant model was the Harvard integrative model

\footnotetext{
${ }^{71}$ In the Australian context writers have commented upon lawyers who co-opt the process of mediation to mirror litigation. An adversarial approach to mediation can rob clients of the benefits of the process and conflict with the Law Council's guidelines relating to lawyers' behaviour in mediation: Peter Callaghan, 'Roles and Responsibilities of Lawyers in Mediation' (2007) 26 The Arbitrator and Mediator 39. For detail regarding the Guidelines see Law Council of Australia, Guidelines for Lawyers in Mediation, New South Wales Bar Association (March 2007) <http://www.nswbar.asn.au/docs/professional/adr/documents/ LAWCOUNCILGUIDELINESFORLAWYERSINMEDIATIONS.pdf>. Many lawyers persist in an adversarial orientation in the mediation process and may use confusing legal terminology and cross-examine parties: Micheline Dewdney, 'Party, Mediator and Lawyerdriven Problems and Ways of Avoiding Them' (2006) 17 Australasian Dispute Resolution Journal 200, 207. Some lawyers do not allow their client to speak and engage in shuttle negotiation: Ruth Charlton, 'Whose Mediation Is This Anyway?' (2007) 45 (1) Law Society Journal 44, 44.

${ }^{72}$ Menkel-Meadow, The Trouble, above n 20, 5.
} 
for negotiation, and the facilitative model of mediation based on the integrative approach. The Harvard approach to negotiation and mediation practice was the standard for both content and pedagogy by the majority of teachers in this study. The Harvard approach dominated the material discussed in class and formed the basis of the model used in role-plays. Many teachers taught the distributive model of bargaining in a seminar or lecture. Only one teacher in the study included this model of negotiation in a role-play as a supplement to the integrative approach to negotiation. Generally, ADR teachers identified the distributive model as an approach to be avoided in ADR.

Significantly, even though the evaluative approach to mediation is widely practised in court-connected contexts, most ADR teachers in stand-alone courses criticised this approach in class, and most did not routinely warn their students about the realities of contemporary legal practice where evaluative ADR may be the norm. For example, two teachers in the study reflected on the ways that they would highlight the drawbacks of the evaluative model to students:

Although we talk about the spectrum of [dispute resolution] in the unit, we focus in on mediation and in that discussion we will say these are the forms of mediation that are available. I talked in my lectures about [the] sort of liability issues and highlighted the fact that liability issues are much more likely to be of concern in evaluative mediation than ... for example facilitative.

I suppose that's the critique aspect of it and the indirect critique is that we teach facilitative.

So I do teach about evaluative mediation and we do talk about it ... how it's different. And we talk about its application in the context of commercial disputes...particularly perhaps commercial disputes where the parties are using, you know, retired judges or eminent lawyers to act as mediators. And we talk a little bit about it in the context of neutrality because clearly there's a significant problem with the idea of neutrality and evaluative [mediation] ... [it] sort of really just doesn't work.

Another teacher noted the dissonance between the primacy of the facilitative model in her teaching of mediation and the realities of practice for her students once they graduate:

I would suspect that once they get out in practice and see at least how mediation is practised in the Supreme Court, for example, in Tasmania, that they'll think it wasn't all it was cracked up to be because it's not practised properly. It's conciliative settlement negotiation, with a big push, so it's not mediation down there. I'd like to think that most of the students go out there 
with the belief that mediation is a really good option but I suspect what then happens is they find that practically it's difficult to do or to do properly.

One teacher took the strong view that it would be inappropriate to teach evaluative mediation otherwise than by critiquing this model. His perspective was that lecturers should promote the ideal of what should occur in practice rather than support the status quo:

No, I don't think you should teach it, well except insofar as it is a way of pointing out some contradictions. I don't think there is a model that's useful... [E]ducational institutions are change agents [and] you shouldn't be reflecting bad practice.

Another teacher in the study, who stated that she taught a range of models, included evaluative mediation, but used only the facilitative models in her role-play strategies:

[I] tend to favour the facilitative and evaluative models myself. Students practise only facilitative mediation.

Where the teachers in this study included the evaluative model of mediation it was mainly to critique the model, although some suggested that they taught the suitability of the evaluative approach in some contexts. None of the teachers used the evaluative model of mediation in role-play simulations. One teacher used the distributive model of negotiation in role-plays and then contrasted this approach with integrative bargaining. This teacher expressed the view that lawyers should be conversant with both models.

Generally, the teachers of stand-alone ADR courses evidenced a desire to effect a normative change to legal practice and to shape the changing legal identity of their students by introducing them to paradigms of non-adversarial practice. This is a laudable objective, although it may lead to some disappointment when students experience ADR processes in legal practice once they graduate. The teachers' commitment demonstrates resistance to the traditional adversarial culture. Their commitment is also in line with much of the policy change in our legal and justice system that promotes nonadversarial practice in law.

\section{Vil Valuing the Spectrum of Legal Processes}

Whilst teachers in this study generally did not support distributive approaches to negotiation, nor the evaluative approach to mediation, they fostered students' understanding of the importance of litigation in appropriate cases. This fits with a key professional belief identified by Macfarlane, namely a 
belief in the 'authority and respect that attaches to the formal legal process'. ${ }^{73}$ Macfarlane found that a belief in the fairness of the system is widely held amongst lawyers, although this belief may not extend to the fairness of outcomes in the legal system. ${ }^{74}$ Many lawyers remain unsure of the meaning of 'justice' for their clients although they believe that the process that clients will experience in the legal system is procedurally fair. Concurrent with this belief is the understanding that a lawyer may exploit the system in their representation of their client to the degree that the system allows: 'Evidently, there is a broad tolerance for procedural games as long as they fall within the given norms of the community of practice or broader culture and they are not seen as a challenge to the fundamental legitimacy of the system. ${ }^{, 75}$

The view that the system of law is procedurally fair and thus has value was supported by some of the participants in this study. Many of the participants valued ADR highly but also valued the option of litigation. This view was expressed by both ADR stand-alone teachers and teachers who combined the teaching of ADR with civil procedure. For example, one participant noted:

[F]or some litigants an adversarial process may be the only way of resolving their problems ... some people do want to have the vindication of a court hearing and a judgment in their favour, so one has to look at the different aspects of the different approaches and see how they fit in with the particular problem a person has.

Similarly, a law teacher noted the importance of a range of approaches in dispute resolution and that litigation should not be sidelined when considering options:

I mean one of my worries about ADR, just as I'm concerned about litigation, is that there'll be people who think that ... I mean they're like one-trick ponies. They seem to think you use the one mechanism in every situation. That's seriously flawed; there is no one mechanism that is going to be well suited to all situations, it just doesn't work like that.

According to Macfarlane, another key professional belief is in the idea of the 'lawyer in charge'. This refers to the lawyers' sense of an entitlement or 'right', drawn from their education and expertise, to assume authority and exercise autonomy in the decisions made regarding a dispute. ${ }^{76}$ For example, one participant noted the drawbacks of this concept of legal practice in contexts where lawyers were called on to work with other disciplines:

\footnotetext{
${ }^{73}$ Macfarlane, above n 1, 54.

${ }^{74}$ Ibid 55.

${ }^{75}$ Ibid 56.

${ }^{76}$ Ibid 59-60.
} 
I don't think lawyers have traditionally ever been very good at multi-disciplinary work, because lawyers, I think, think that legal knowledge is superior to a lot of other knowledge.

Most lawyers believe that clients should accede to the advice of the lawyer regarding both strategy and the merits of a dispute. ${ }^{77}$ The lawyer has the 'technical expertise' ${ }^{78}$ that places him or her in a position of power vis-à-vis the client. In Macfarlane's view, 'the roots of such assumptions over power and control in the lawyer-client relationship lie in the epistemology of law school and professional legal training'. ${ }^{79}$

In this study participants identified the need to teach law students to 'think like a lawyer'. A part of this approach to legal education includes teaching the technical knowledge associated with being a lawyer:

I think students should be able to think like a lawyer, in a sense of being able to critically analyse information, sift through a whole lot of stuff and work out what's important, and go to the right facts, work out how to provide advice and so on. I think that that's really important.

Another participant noted the importance of understanding substantive law relating to litigation as well as the role of ADR:

I think it's important for the students to know the procedural rules of the Supreme Court as a model and also the County Court and Magistrates' Court. It's important for them to know the various time limits and it's important for them to know ... the function of pleadings etc. Those things are just as important as ADR.

Some participants also identified the subject of legal education as largely black-letter law, studied against the background of a litigation-focused culture:

I think our focus is very much a litigation-based focus throughout the whole of the curriculum and so I think students do end up with a partisan mindset.

Another participant noted the focus upon cases as the dominant feature of law teaching:

\footnotetext{
${ }^{77}$ Ibid 60-1.

${ }^{78}$ This technical expertise is highly valued in business and arguably dominates legal education at the expense of socio-legal critique of the law: Margaret Thornton, 'The Demise of Diversity in Legal Education: Globalisation and the New Knowledge Economy’ (2001) 8 International Journal of the Legal Profession 37, 37-8.

${ }^{79}$ Macfarlane, above n 1, 60.
} 
[M]any lawyers will still teach with a case-book approach and a problem solving approach and the reality of practice is that ... most young lawyers seldom actually get into a litigated trial these days, that really the practice floor is about negotiation and about analytical and reasoning skills. And I don't think that the negotiation and communication skills that are essential are well supported in many law schools at all.

Lawyers of the future need to cultivate understanding and skills that assist in the majority of practice. As this participant noted, communication skills are essential in this new role. Further, as noted previously, TLO 5 in the law standards requires learning communication-oriented outcomes for students.

In tracing the paradigm of 'lawyer in charge', Macfarlane notes that clients fall into two categories: clients for commercial and for personal services. Where the client is a commercial one, the 'lawyer in charge' paradigm may not be dominant and lawyers may be required actively to engage with the client in decision-making. ${ }^{80}$ In contrast, personal services clients tend to be less assertive, but the literature relating to access to justice has recently supported the notion that it is desirable that a client be active in this context as well as the commercial context. ${ }^{81}$ The rights-based focus of much of legal practice, and the privileging of the adversarial model, can contribute to the 'lawyer in charge' paradigm of practice. The technical power of the lawyer (the understanding of legislation and relevant case law) means that the account of the legal dispute that the client brings to the lawyer is reduced to a story of rights-based concerns. Other interests, such as the emotional, personal and business interests of the client, may be marginalised; the focus tends to be upon facts that support legal arguments. As Macfarlane notes:

A traditional adversarial model of legal services that centers on technical advice - 'taking instructions', which in effect means telling the client what is best for them - allows lawyers to control the relationship between themselves and their clients. It limits their professional role to that of technical expert (with which they are generally comfortable) and at the same time limits the intrusion of emotional and other less predictable dimensions of conflict resolution. ${ }^{82}$

A focus on rights in the framing of solicitor/client interactions is a traditional view of practice. The increase in ADR options in courts and the policy practices of governments resist these traditional beliefs. In Macfarlane's view, a change to lawyers' culture does not require a paradigm change, but rather an evolution of practice, a shift of lawyers' focus from litigation to collaborative

\footnotetext{
${ }^{80}$ Ibid.

${ }^{81}$ Ibid 59-60.

${ }^{82}$ Ibid 62.
} 
problem-solving. ${ }^{83}$ In the Australian legal profession it is unclear how much non-adversarial practice has been adopted, and there is a need for comprehensive research to establish the state of play. ${ }^{84}$ Critically, lawyers of the future will need to be schooled in ADR and understand non-adversarial frames of practice.

\section{CONCLUSION}

This article has considered the construction of adversarialism in legal practice, and has canvassed an alternative practice that is sometimes termed 'nonadversarial', relying on interest-based negotiation and collaborative problemsolving. In summary, the findings of the research demonstrate that ADR teachers, in both stand-alone courses and those combined with civil procedure, value ADR and non-adversarial practice in law. In particular, those teachers who taught stand-alone ADR courses had a commitment to their students understanding the full range of options available to parties to resolve conflict, including negotiation and mediation. Teachers spoke of the need to discuss all options in dispute resolution and the importance of the use of litigation in some disputes. Participants in this research who taught standalone ADR courses largely adopted Harvard integrative bargaining paradigms. Non-adversarial practice was well supported by the teachers in this study who taught ADR as a stand-alone course. However, these teachers were not confident that the legal profession had made a similar shift in approach to practice. Despite their commitment to non-adversarial practices these teachers did not reject litigation as an option in the ADR spectrum and believed that students should understand that litigation is appropriate for some disputes.

The commitment to non-adversarial practices led most teachers of stand-alone courses to critique the distributive approach to negotiation and the evaluative model of mediation. Only two of the group who taught in stand-alone ADR courses expressed strong support for these approaches. However, it is of concern that the majority of teachers in this study are not preparing students adequately for the realities of legal practice, where distributive and evaluative practices generally dominate. Therefore, teachers of ADR should teach more consistently with prevailing practice and address both the distributive and evaluative approaches. They should use role-plays that include the evaluative approach and industry experts should be invited to speak about the realities of practice and how new solicitors might deal with these kinds of practice paradigm.

\footnotetext{
${ }^{83}$ Ibid 96-7.

${ }^{84}$ Wolski, above n 59, 211-15.
} 
Overall, the teachers who participated in this study are largely proponents and advocates of non-adversarial practice and thus might be said to be contributing to an evolution in legal culture. These teachers are breaking new ground in educating lawyers of the future to understand and adopt nonadversarial approaches such as negotiation and mediation. The teachers do not abandon teaching about the option of litigation, but rather assist students to see that there is also value in practising in a non-adversarial manner. Such education for law students is in line with changing norms in practice. From this study it is clear that ADR teachers are shaping law students to develop professional identities that will assist them to engage effectively in present day legal practice. 